STUDIA HISTORICA GEDANENSIA

TOM VIII (2017)

\title{
Karol Staniszewski
}

(Kujawsko-Pomorska Szkoła Wyższa w Bydgoszczy)

\section{Działalność polskich organizacji rolniczych w Prusach Zachodnich w latach 1850-1890 na rzecz rozwoju rolnictwa polskiego w świetle pomorskiej prasy polskiej}

Niniejszy artykuł jest poświęcony działalności polskich organizacji rolniczych w Prusach Zachodnich w latach 1850-1890 na rzecz rozwoju rolnictwa w kontekście zmagań konkurencyjnych w dziedzinie gospodarki ze społecznością niemiecką. Głównym materiałem badawczym jest prasa polska Prus Zachodnich. Jest to próba całościowego ujęcia zagadnienia. Dotychczasowa literatura naukowa przedmiotu poświęcona temu zagadnieniu jest stosunkowo obszerna, lecz nie ujmuje tego zagadnienia w sposób całościowy (tzn. w latach 1850-1890), na łamach polskiej prasy Prus Zachodnich. Dotychczas, w mniejszym lub większym stopniu, tematykę gospodarki, rolnictwa, organizacji rolniczych i wzajemnych relacji polsko-niemieckich w swoich badaniach podejmowali: Jacek Banach, Józef Borzyszkowski, Andrzej Bukowski, Tadeusz Cieślak, Bolesław Danilczuk, Adam Domański, Grażyna Gzella, Ryszard Michalski, Marian Mroczko, Andrzej Romanow, Lech Trzeciakowski, Kazimierz Wajda, Szczepan Wierzchosławski, Bronisław Woźniczka-Paruzel i Wojciech Wrzesiński ${ }^{1}$.

1 Jacek Banach, Prasa polska Prus Zachodnich w latach 1848-1914 (Gdańsk: Wydawnictwo Uniwersytetu Gdańskiego, 1999); idem, „Chełmiński »Przyjaciel Ludu « w okresie redakcji Ignacego Danielewskiego (1860-1869)”, Rocznik Gdański 51(2) (1996): 35-50; idem, „Chełmno - pierwszym polskim ośrodkiem prasowym w Prusach Zachodnich", Rocznik Grudziądzki 12 (1996): 49-73; idem, „»Nadwiślanin « (1859-1866) - poprzednik »Gazety Toruńskiej «”, Rocznik Gdański 1 (1999): 47-60; idem, „Toruński »Przyjaciel«. Zapomniana gazeta z okresu zaboru (1876-1917)”, Rocznik Toruński 19 (1990): 179-202; idem, „Pelpliński »Pielgrzym« czołowym pismem polskim w Prusach Zachodnich przed I wojną światową", Studia Pelplińskie 19 (1988): 265-275; Józef Borzyszkowski, „»Pielgrzym " - gazeta i wydawnictwo w Pelplinie 1869-1939”, w W kręgu książki (Gdańsk: Wydawnictwo Morskie, 1987); Andrzej Bukowski, „»Gazeta Toruńska « (1867-1921)”, Rocznik Toruński 3 (1969): 99-129; Tadeusz Cieślak, „Prasa pomorska na przełomie XIX i XX wieku”, Przeglą Zachodni 2 (1957): 190-207; idem, „Prasa polska na Pomorzu w drugiej połowie XIX i w początkach XX wieku”, w Pomorze na progu dziejów najnowszych, red. idem (Warszawa: Książka i Wiedza, 1961), 
W warunkach zaboru pruskiego walka o polskośćłączona była z dążeniem do utrzymania polskiego stanu posiadania, głównie w rolnictwie, poprzez m.in. utrzymanie

286-307; idem, Z dziejów prasy polskiej na Pomorzu Gdańskim w okresie zaboru pruskiego (Gdańsk: Gdańskie Towarzystwo Naukowe, 1964); idem, Prasa Pomorza Wschodniego w XIX i XX wieku (Warszawa: Państwowe Wydawnictwo Naukowe, 1966); idem, „Prasa polska na Śląsku, Pomorzu i Mazurach w latach 1832-1870”, w Dzieje prasy polskiej, red. Jerzy Łojek (Warszawa: Interpress, 1988); Łojek, Prasa polska w latach 1661-1864 (Warszawa: Państwowe Wydawnictwo Naukowe, 1976), 260-272; idem, „Prasa w zaborze pruskim (Śląsk, Pomorze, Warmia, Mazury) w latach 1871-1918”, w Historia prasy polskiej, red. idem; idem, „»Biedaczek«. Czasopismo ludowe z okresu Wiosny Ludów”, Rocznik Historii Czasopiśmiennictwa Polskiego 1 (1962): 112-127; Bolesław Danilczuk, „Chełmno w okresie zaboru pruskiego (XIX-pocz. XX w.)”, w Dzieje Chetmna i jego regionu. Zarys monograficzny, red. Marian Biskup (Toruń: Toruńskie Towarzystwo Naukowe,1968), 201-251; Danilczuk, „Tło społeczno-polityczne »Gazety Toruńskiej «”, Rocznik Toruński (3) 1969: 131-140; Adam Domański, "Julian Walenty Prejs i jego »Biedaczek«", cz. 1, w Studia o działalności i zbiorach biblioteki UMK, cz. 2 (Toruń: Wydawnictwo Uniwersytetu Mikołaja Kopernika, 1982), 119-138; Grażyna Gzella, „Pisma dla ludu” pod zaborami w pierwszej połowie XIX wieku (Toruń: Wydawnictwo Uniwersytetu Mikołaja Kopernika, 1994); idem, „Zaborcy i ich polityka wobec Polaków w ocenie redaktora »Biedaczka« (1848-1850)", w Szkice z dziejów piśmiennictwa pomorskiego XVII-XIX wieku, red. B. Woźniczka-Paruzel (Toruń: Wydawnictwo Uniwersytetu Mikołaja Kopernika, 1999), 77-85; Ryszard Michalski, Systemy wartości na łamach polskiej prasy pomorskiej w latach 1870-1939 oraz 1945-1980 (Toruń: Wydawnictwo Uniwersytetu Mikołaja Kopernika, 1998); Marian Mroczko, Ziemie dzielnicy pruskiej w polskich koncepcjach i działalności politycznej 1864-1939 (Gdańsk: Wydawnictwo Uniwersytetu Gdańskiego, 1994); Andrzej Romanow, „Pielgrzym” pelpliński w latach 1869-1920 (Gdańsk-Pelplin: Instytut Kaszubski, 2007); Lech Trzeciakowski, Pod pruskim zaborem: 1850-1918 (Warszawa: Wiedza Powszechna, 1973); idem, „Polacy i Niemcy w drugiej połowie XIX wieku”, w W kregu polityki. Polacy i Niemcy w XIX wieku (Poznań: Instytut Historii Uniwersytetu im. Adama Mickiewicza, 2002); Kazimierz Wajda, Stosunki ludnościowe na ziemiach polskich $w$ latach 1850-1914, w Historia Pomorza, t. 4, 1850-1918, cz. 1, Ustrój, gospodarka, społeczeństwo, red. Stanisław Salmonowicz (Toruń: Wydawnictwo Towarzystwa Naukowego, 2000); idem, „Przemiany w polskim stanie posiadania ziemi na Pomorzu Gdańskim w drugiej połowie XIX i na początku XX wieku”, Zapiski Historyczne 4 (1972); idem, Wieś pomorska na przełomie XIX i XX wieku. Kwestia rolna na Pomorzu Gdańskim (Poznań: Wydawnictwo Poznańskie, 1964); Szczepan Wierzchosławski, Polski ruch narodowy w Prusach Zachodnich w latach 1860-1914 (Wrocław-Warszawa-Kraków: Zakład Narodowy im. Ossolińskich, 1980); idem, „Prasa chełmińska w okresie zaboru pruskiego”, Życie i Myśl 7-8 (1985): 76-87; idem, „Od upadku Polski do odzyskania niepodległości 1795-1920”, w Dzieje Chetmna. Zarys monograficzny, red. Biskup (WarszawaPoznań-Toruń: Państwowe Wydawnictwo Naukowe, 1987), 197-280; Wierzchosławski, „Polski ruch narodowy", w Historia Pomorza, t. 4, 1850-1918, cz. 2, Polityka i kultura, red. Salmonowicz (Torun: Wydawnictwo Towarzystwa Naukowego, 2002), 172; Wierzchosławski, Ignacy Lyskowski 1820-1886. Polityk i publicysta, pierwszy prezes Towarzystwa Naukowego w Toruniu (Toruń: TNT, 2000); idem, Elity polskiego ruchu narodowego w Poznańskiem i w Prusach Zachodnich w latach 1850-1914 (Toruń: TNT, 1992); idem, Orzeł czarny i orzeł biały. Problemy modernizacji społeczeństwa polskiego prowincji Prusy Zachodnie w XIX i na początku XX stulecia (Olsztyn: Littera, 2011); Bronisława Woźniczka-Paruzel, „Strategie obrony narodowości w polskich czasopismach i książkach dla ludu Prus Zachodnich z lat 1848-1880", w Studia z dziejów polskiej myśli politycznej, t. 3, red. Sławomir Kalembka (Toruń: Wydawnictwo Uniwersytetu Mikołaja Kopernika, 1990), 161-202; Wojciech Wrzesiński, „Ze studiów nad obliczem ideowo-politycznym »Gazety Toruńskiej« (1867-1914)”, Zapiski Historyczne 3 (1979): 93-129. 
w polskich rękach jak największej ilości ziemi. Oczywiście uznawano także rolę i wagę innych gałęzi gospodarki².

Jednak posiadanie ziemi przez Polaków urastało ówcześnie do rangi symbolu i patriotycznej powinności. W tym kontekście istotna rola w zmaganiach o polski stan posiadania przypadła polskim organizacjom rolniczym. W artykule przedstawiono aspekty działalności polskich organizacji rolniczych, jak i poszukiwane przez nie drogi wydatniejszego rozwoju rolnictwa w Prusach Zachodnich.

Ważne aspekty artykułu to walka o polski stan posiadania w rolnictwie oraz problematyka tzw. pracy u podstaw. Tematyka ta była kształtowana przez ówczesną prasę polską jako szczególne panaceum na utrzymanie polskiego stanu posiadania w dobie postępującej konkurencji ze strony niemieckiej.

Obszarem badań są Prusy Zachodnie (Provinz Westpreussen), w których skład wchodziło Pomorze Gdańskie oraz Ziemia Chełmińska. Termin „Prusy Zachodnie” jako prowincja był używany w XIX w. zamiennie z terminami „Pomorze Gdańskie” i „Ziemia Chełmińska” - potwierdza to także terminologia stosowana w ówczesnej prasie polskiej omawianego okresu. Do 1824 r. Prusy Zachodnie stanowiły samodzielną jednostkę terytorialną. W 1824 r. Prusy Zachodnie i Prusy Wschodnie zostały połączone w jedną centralną prowincję (do 1878 r.). Odtąd siedzibą władz prowincji stał się Królewiec 3 . W 1878 r. powrócono do istniejącej w latach 1815-1824 samodzielnej prowincji Prusy Zachodnie (Westpreussen). Odtąd stolicą prowincji Prusy Zachodnie stał się Gdańsk"

Jako kryterium doboru ram chronologicznych artykułu przyjąłem lata, które były granicznymi dla ekip rządowych sprawujących ówcześnie władzę w Prusach (następnie od 1871 r. w Niemczech). Rok 1850 to okres końcowy Wiosny Ludów i początek reakcyjnej ery Manteuffla, która trwała do 1858 r. Rok 1890 natomiast kończy sprawowanie rządów Ottona Bismarcka, którego okres władzy stanowił pewną długą epokę w dziejach Prus i Niemiec (od 1871 r.). Lata 1850-1890 obejmują więc okres sprawowania władzy przez poszczególne ekipy dzierżące władzę w Prusach i Niemczech.

Prusy Zachodnie w omawianym okresie były silnie zasiedlone przez ludność niemiecką, co było wynikiem długotrwałego procesu historycznego ${ }^{5}$. Dokładna liczba

2 Stefan Kowal, Społeczeństwo Wielkopolski i Pomorza Nadwiślańskiego w latach 1871-1914: przemiany demograficzne i społeczno-zawodowe (Poznań: Wydawnictwo Naukowe UAM, 1982), 18-29, 37-47.

3 Tadeusz Cieślak, Pomorze Wschodnie w XIX i XX wieku ze specjalnym uwzględnieniem podziałów administracyjnych (Olsztyn: Stowarzyszenie Społeczno-Kulturalne „Pojezierze” 1966), 26. Dekretem królewskim z dnia 25 VI 1823 powołano w prowincjach pruskich zgromadzenia prowincjonalne; $\mathrm{w}$ tym roku wprowadzono także jeden sejmik prowincjonalny dla Prus Wschodnich i Zachodnich. Na mocy rozporządzenia królewskiego z dnia 13 IV 1824 połączono funkcje dwóch prezesów prowincji w jedną, a na mocy zarządzenia z dnia 3 XII 1829 połączono reprezentację stanową dwóch byłych prowincji.

4 Salmonowicz, „Administracja i prawo w prowincjach pomorskich”, w Historia Pomorza, t. 4, 1850-1918, cz. 1, Ustrój, gospodarka, społeczeństwo, 39.

5 Witold Molik, „Procesy asymilacyjne i akulturacyjne w stosunkach polsko-niemieckich w XIX i na początku XX wieku. Stan i postulaty badań”, w Procesy akulturacji/asymilacji na pograniczu 
osób zamieszkujących Prusy Zachodnie i zaliczanych do narodowości polskiej i niemieckiej jest trudna do ustalenia, co ma związek z małą wiarygodnością pruskich spisów językowych prowadzonych do lat sześćdziesiątych XIX w. ${ }^{6}$

W latach 1849-1890 liczba mieszkańców Prus Zachodnich wzrosła z 1028018 do 1433681 w 1890 r. $^{7}$

W 1861 r. ogółem w Prusach Zachodnich zarejestrowano 790765 osób mówiących językiem niemieckim i 379403 osób - językiem polskim . Według władz pruskich zaś w 1861 r. w Prusach Zachodnich mieszkało 790467 Niemców oraz 399934 Polaków9.

Powstanie i rozwój polskich towarzystw rolniczych w zaborze pruskim (w tym i w Prusach Zachodnich) w drugiej połowie XIX w. łączy się z istnieniem Ligi Polskiej, która programowo głosiła hasła organicznikowskie, zwracając uwagę na wszechstronny rozwój narodowości polskiej - w tym także umacnianie się $\mathrm{w}$ dziedzinie gospodarczej ${ }^{10}$.

W 1850 r. w Prusach Zachodnich powstało Towarzystwo Rolnicze na Prawy Brzeg Wisły - obejmujące ziemię michałowską i chełmińską - jego siedzibą było Wąbrzeźno ${ }^{11}$. W 1857 r. towarzystwo to zostało podzielone na dwa - jedno dla ziemi chełmińskiej; drugie zaś dla ziemi michałowskiej ${ }^{12}$. W 1850 r. z kolei na lewym brzegu Wisły powstały dwa towarzystwa: dla ziemi północno-pomorskiej (siedziba - Starogard) i ziemi południowo-pomorskiej (siedziba - Tuchola) ${ }^{13}$.

W gospodarce początek lat sześćdziesiątych XIX w. charakteryzował się w Prusach Zachodnich gwałtownym rozwojem polskich organizacji rolniczych zakładanych najczęściej przez ziemian i księży. Na rozwój ten wpłynęło kilka czynników, do których na pierwszym miejscu należy wymienić wyklarowanie się korzystnej

polsko-niemieckim w XIX i XX wieku, red. idem, Robert Traba (Poznań: Grami, 1999), 91; Wierzchosławski, Polski ruch narodowy, 14.

6 Wajda, Stosunki ludnościowe na ziemiach polskich w latach 1850-1914, 102.

7 Ibidem, 108.

8 Wierzchosławki, Polski ruch narodowy, 15-16.

9 Ibidem, 16-17.

10 Cyt. za: Walery Rutkowski, Towarzystwa rolnicze polskie w Prusach Zachodnich. Rys historyczny $i$ wykaz statystyczny istniejacych Towarzystw rolniczych (Poznań, 1895), 6 - był to $₫ 1$ ustawy organicznej Ligi Polskiej: „Liga Polska ma na celu utrzymanie, bronienie, popieranie i rozwijanie sprawy narodowej polskiej na drodze jawności i legalności”.

11 Ibidem, 7 - prezesem tego towarzystwa został Natalis Sulerzyski.

12 Ibidem, 7-8 - w 1865 Towarzystwo Rolnicze Ziemi Chełmińskiej zostało podzielone na trzy powiatowe: chełmińskie, grudziądzkie i toruńskie.

13 Ibidem, 7, 9-10, 14 - Towarzystwo Rolnicze Ziemi Północno-Pomorskiej założone zostało w 1858 i obejmowało powiat starogardzki, południową część powiatu kościerskiego oraz tczewskiego. Zostało założone przez H. Jackowskiego (który powołał także osobne towarzystwo rolnicze w Zblewie) 3 VI 1862. W 1866 postanowiono o rozwoju tego towarzystwa w parafiach - w powiecie świeckim powstało wtedy sześć takich towarzystw parafialnych: w Drzycimiu, Grucznie, Osiu, Przysiersku, Lubiewie, Komorsku, w powiecie chojnickim zaś: w Tucholi, Śliwicach, Czersku i Łęgu, ponadto także w Serocku i Świekatowie. W 1869 z kolei postanowiono o podziale Towarzystwa Rolniczego Ziemi Południowo-Pomorskiej na powiatowe: świecko-chojnickie, człuchowskie, złotowskie i wałeckie. 
sytuacji politycznej w państwie pruskim od 1859 r., co było związane ze zwycięstwem frakcji liberalnej ${ }^{14}$.

Według Bukowskiego często ukrywały one cele polityczne zbieżne z żywotnymi dążeniami narodowymi Polaków ${ }^{15}$. W tych nowo powstających towarzystwach większość członków stanowili chłopi. Na początku lat sześćdziesiątych XIX w. założono następujące towarzystwa rolnicze w Prusach Zachodnich: Towarzystwo Agronomiczne w Brodnicy (powstało 13 września 1861 r.), Towarzystwo Rolnicze Ziemi Chełmińskiej (21 stycznia 1862 r.), Towarzystwo Rolnicze Ziemi Kaszubskiej (17 marca 1862 r.), Towarzystwo Rolnicze Ziemi Pomorskiej (dla powiatów starogardzkiego i przyległych - 9 kwietnia 1862 r.); Towarzystwo Rolnicze Ziemi Południowo-Pomorskiej ( 2 czerwca 1862 r.), Towarzystwo Rolnicze w Piasecznie (1 października 1862 r.) i Towarzystwo Rolnicze Ziemi Malborskiej (20 stycznia 1863 r. $)^{16}$. Twórcą Towarzystwa Rolniczego w Piasecznie był Juliusz Kraziewicz z Tymawy. Było to pierwsze kółko włościańskie ${ }^{17}$.

Powstające towarzystwa rolnicze, propagując poradnictwo rolnicze, miały zahamować niekorzystną dla Polaków tendencję przejawiającą się w stopniowym przejmowaniu areałów ziemskich w Prusach Zachodnich przez gospodarzy niemieckich. Od połowy lat sześćdziesiątych XIX w. niektóre nowo powstałe towarzystwa rolnicze dążyły do utworzenia towarzystw filialnych znajdujących się w obrębie najbliższych parafiii ${ }^{18}$.

Kółka rolnicze różniły się od rolniczych organizacji ziemiańskich między innymi stosunkowo mniejszym zasięgiem terytorialnym ${ }^{19}$. Szybki rozwój kółek

14 Andrzej Bukowski, Juliusz Kraziewicz (1829-1895) pionier polskich kółek rolniczych (Gdańsk: Krajowa Agencja Wydawnicza, 1978), 13.

15 Ibidem, 14.

16 Rutkowski, Towarzystwa rolnicze, 8-9, 15-16; Bukowski, Juliusz Kraziewicz, 13-14. Z towarzystw okręgowych (kółek włościańskich) powstałych w powiecie brodnickim na uwagę zasługuje Towarzystwo w Wielkim Pułkowie. Rutkowski napisał, że Towarzystwo Rolnicze Ziemi Malborskiej zostało założone w 1865. Początkowo powstały dwa towarzystwa - w Starym Targu i w Podstolinie. W 1870 założono także towarzystwo rolnicze w Pierzchowicach - w 1880 przestało ono istnieć. Według wspomnianego autora na ziemi malborskiej istniało także Towarzystwo Rolnicze w Trzcianie.

17 Rutkowski, Towarzystwa rolnicze, 16; Peter Böhning, Die Nationalpolnische Bewegung in Westpreussen 1815-1871 (Marburg-Lahn: J.G. Herder Institut, 1973), 119: „Am 1.10.1862 gründete er in Pehsken (Piaseczno) das erste, kółko włościańskie '[Bauernverein. Wörtlich: bauerlicher Ring]. Der Verein war ausschließlich für selbständige Bauern [włościanie] und deren spezielle Bedürfnisse bestimmt. Mit seiner Organisation und Tätigkeit gewann er Modellcharakter für alle folgenden Gründungen dieser Art in Westpreußen und dem Großherzogtum”; Bukowski, Juliusz Kraziewicz, 16.

18 Bukowski, Juliusz Kraziewicz, 33-34 - tak było w przypadku np. Towarzystwa Rolniczego Ziemi Kaszubskiej - podczas zebrania tego towarzystwa w VI 1864 w Kościerzynie wnioskowano o utworzenie dziewięciu filii w miejscowościach powiatów kartuskiego i kościerskiego (w Kościerzynie, Starej Kiszewie, Wysinie, Lipuszu, Sierakowicach, Sulęczynie, Chmielnie, Żukowie, Goręczynie). Towarzystwo Rolnicze Ziemi Michałowskiej zalecało zaś w XII 1864 utworzenie parafialnych organizacji rolniczych.

19 Ibidem, 34. 
rolniczych w Prusach Zachodnich przyniosła druga połowa XIX w. Dnia 22 sierpnia 1865 r. powstało Towarzystwo Rolnicze Powiatu Lubawskiego ${ }^{20}$. Towarzystwo to zostało podzielone na dwa okręgowe - tj. lubawskie i nowomiejskie ${ }^{21}$. W powiecie kartuskim istniało od $1865 \mathrm{r}$. Towarzystwo Rolnicze w Chmielnie ${ }^{22}$. W $1866 \mathrm{r}$. założono, wzorując się na Towarzystwie Rolniczym w Piasecznie, towarzystwa rolnicze w Pieniążkowie (powstało 15 lutego 1866 r.), Pelplinie (8 maja 1866 r.) i Bobowie (24 maja 1866 r. $)^{23}$. Na Kaszubach towarzystwo założył także Florian Ceynowa (2 stycznia 1866 r. powstało Towarzystwo Rzemieślniczo-Przemysłowe Kaszubsko-Słowiańskiego Narodu) ${ }^{24}$. W 1866 r. rozpoczęło działalność Towarzystwo Rolnicze Powiatu Toruńskiego, które powstało po podziale Towarzystwa Rolniczego Ziemi Chełmińskiej ${ }^{25}$. W tym samym roku zaczęło działać Towarzystwo Rolnicze Powiatu Grudziądzkiego powstałe także po rozwiązaniu Towarzystwa Rolniczego Ziemi Chełmińskiej ${ }^{26}$.

W 1867 r. podzielono je na dwa towarzystwa okręgowe - jedno z siedzibą w Radzynie, drugie w Łasinie ${ }^{27}$. Dnia 24 kwietnia 1866 r. założono Towarzystwo Rolnicze dla Powiatu Kościerskiego; towarzystwo to utworzono z Towarzystwa Rolniczego Ziemi Kaszubskiej ${ }^{28}$. Dnia 25 czerwca 1867 r. powstało Towarzystwo Rolnicze w Skórczu, zaś 30 czerwca 1867 r. - Towarzystwo Rolnicze w Lubichowie ${ }^{29}$.

W 1868 r. utworzono w powiecie wejherowskim Towarzystwo Rolnicze na Oksywiu oraz Towarzystwo Rolnicze w Kwaszynie pod Oliwą (było ono filią Towarzystwa Rolniczego na Oksywiu) ${ }^{30}$. Dnia 7 października 1868 r. powstało Towarzystwo Rolnicze w Komorsku ${ }^{31}$.

W roku 1870 zostało założone Towarzystwo Rolnicze w Wąbrzeźnie jako okręgowe po rozwiązaniu Towarzystwa Rolniczego Powiatu Chełmińskiego ${ }^{32}$.

\footnotetext{
20 Rutkowski, Towarzystwa rolnicze, 17.

$21 \quad$ Ibidem, 18.
}

${ }^{22}$ Ibidem - w powiecie kartuskim działało także Towarzystwo Rolnicze w Sierakowicach założone w 1870 .

${ }_{23}$ Rutkowski, Towarzystwa rolnicze, 17, 22-26; Bukowski, Juliusz Kraziewicz, 36-39 - Towarzystwa Rolnicze w Piasecznie i Pieniążkowie zostały zawiązane w 1888. Towarzystwo Rolnicze w Pelplinie przestało istnieć w 1875 i dopiero w 1890 zawiązano nowe Towarzystwo Rolnicze w Pelplinie na powiaty: kwidzyński, starogardzki, tczewski.

24 Ibidem, 28 - posiedzenia tego towarzystwa odbyły się w Świeciu, Brusach, Smełdzeniu i Sztumie. Założenie tego towarzystwa miało miejsce w Oliwie pod Gdańskiem.

25 Ibidem, 18.

26 Ibidem, 19.

27 Ibidem, 19-20 - Towarzystwo Rolnicze w Radzynie zostało gruntownie zreorganizowane w 1883.

28 Ibidem, 26.

29 Bukowski, Juliusz Kraziewicz, 40 - jak podał autor na terenie powiatu tucholskiego i świeckiego powstały także Towarzystwa Rolnicze w Grucznie, Drzycimiu, Lubiewie i Tucholi.

30 Rutkowski, Towarzystwa rolnicze, 27-28.

31 Bukowski, Juliusz Kraziewicz, 39.

32 Rutkowski, Towarzystwa rolnicze, 28 - Towarzystwo Rolnicze w Wąbrzeźnie nosiło początkowo nazwę Towarzystwa Rolniczo-Przemysłowo-Politycznego ostatecznie zmieniając nazwę 
W 1873 r. powstało Towarzystwo Rolnicze w Lidzbarku (w powiecie Brodnickim) ${ }^{33}$. Według Walerego Rutkowskiego do 1890 r. w Prusach Zachodnich założone zostały ponadto następujące towarzystwa rolnicze: Towarzystwo Rolnicze w Mechowie (4 listopada 1875 r.), Towarzystwo Rolniczo-Przemysłowe na Powiat Tucholski w Tucholi (29 grudnia 1889 r.), Towarzystwo Rolniczo-Przemysłowe w Czersku (1890 r.), Towarzystwo Rolniczo-Przemysłowe w Nowemmieście (18 marca 1890 r.), Towarzystwo Rolnicze dla Powiatów Starogardzkiego, Tczewskiego i Kwidzyńskiego w Pelplinie (21 września 1890 r.) ${ }^{34}$.

Na początku $1868 \mathrm{r}$. w Prusach Zachodnich istniały 24 towarzystwa rolnicze oraz drobne kółka wiejskie, natomiast w roku 1875 liczba ta wynosiła już $49^{35}$. Do 1874 r., według Rutkowskiego, działało w Prusach Zachodnich 18 towarzystw rolniczych, a wśród nich 22 mniejsze okręgowe kółka rolnicze ${ }^{36}$. Z kolei dane zamieszczone przez Zarząd Centralny Towarzystw Rolniczych dla Prus Zachodnich wskazują, że do 1874 r. istniało w Prusach Zachodnich 35 towarzystw rolniczych ${ }^{37}$.

Na początku lat siedemdziesiątych XIX w. polscy działacze gospodarczy w zaborze pruskim doprowadzili do unifikacji działalności organizacji polskich, zakładając w 1871 r. Związek Spółek Zarobkowych i Gospodarskich (ZSZiG) ${ }^{38}$. Do istnienia powołali go delegaci spółek pomorskich i z Prus Zachodnich. Miał koordynować działalność instytucji pożyczkowych i gospodarczych; na jego czele

na rolnicze; w 1870 zostało założone także Towarzystwo Rolnicze w Lisewie powstałe po rozpadzie Towarzystwa Rolniczego Powiatu Chełmińskiego.

33 Rutkowski, Towarzystwa rolnicze, 29.

34 Ibidem, 50-53.

35 Bukowski, Juliusz Kraziewicz, 40, 65; J. Jasiński, „Zagadnienia polityczne i narodowościowe lat 1850-1871", w Historia Pomorza, t. 4, 1850-1918, cz. 2, Polityka i kultura, 62. Według autora w latach 1862-1871 powstało w Prusach Zachodnich 50 towarzystw rolniczych, wliczając w to także spółki pożyczkowe.

36 Rutkowski, Towarzystwa rolnicze, 29.

37 Ibidem, 34-35. Były to towarzystwa:

„I. W powiecie Toruńskim: 1) w Chełmży, 2) Kowalewie i 3) Korytach.

II. W powiecie Chełmińskim: 4) w Wąbrzeźnie i 5) Lisewie.

III. W powiecie Brodnickim: 6) w Brodnicy, 7) Półkowie, 8) Zbicznie, 9) Górznie i 10) Góralach.

IV. W powiecie Lubawskim: 11) w Lubawie i 12) w Nowemmieście.

V. W powiecie Kwidzyńskim: 13) w Piasecznie, 14) w Pieniążkowie.

VI. W powiecie Sztumskim: 15) w Starymtargu, 16) w Pierzchowicach i 17) w Trzcianie.

VII. W powiecie Starogardzkim: 18) w Bobowie i 19) w Pączewie.

VIII. W powiecie Kościerskim: 20) w Kościerzynie, 21) w Kiszewie i 22) w Pogutkach.

IX. W powiecie Wejherowskim: 23) na Oksywiu.

X. W powiecie Kartuskim: 24) w Sierakowicach.

XI. W powiecie Chojnickim: 25) w Śliwicach, 26) w Łęgu, 27) w Brusach, 28) w Gostyczynie, 29) w Karszynie i 30) w Tucholi.

XII. W powiecie Świeckim: 31) w Lubiewie, 32) w Błońdźminie, 33) Grucznie, 34) w Drzycimiu i 35) w Osiu".

38 Wierzchosławski, Polski ruch narodowy, w Historia Pomorza, 172. 
stał patron oraz sześcioosobowy komitet ${ }^{39}$. W 1873 r. objęto tzw. patronatem (stanowisko to objął Maksymilian Jackowski) działalność chłopskich kółek rolniczych. Urząd ten oprócz koordynacji pracy organizacji miał także za zadanie zachowanie przywódczej roli szlachty nad uwłaszczonym chłopstwem, tak aby te dwie klasy społeczne występowały solidarnie przeciw niemieckiej dominacji narodowościowej i gospodarczej ${ }^{40}$.

W 1874 r. powołano w Toruniu Centralny Zarząd Towarzystw Rolniczych w Prusach Zachodnich. Organizacja ta oprócz charakteru gospodarczego (postulując w tym względzie m.in. tworzenie nowych towarzystw rolniczych) miała także charakter oświatowy, co przejawiało się w rozpowszechnianiu prasy polskiej ${ }^{41}$.

Tematyka dotycząca poradnictwa gospodarczego po raz pierwszy w prasie polskiej Prus Zachodnich omawianego okresu (1850-1890) została podjęta na łamach pisma „Biedaczek”. W jednym z pierwszych numerów tego pisma (z 1850 r.) redakcja zamieściła artykuł Dlaczego to Polacy tak strasznie ubożejąㄹ w którym zaprezentowano poglądy propagujące hasła "prac organicznych", proponując wzorzec Polaka pracowitego, pragmatycznego, funkcjonującego w ramach „solidaryzmu narodowego". Wspomniana afirmacja programu „solidaryzmu narodowego" miała na celu m.in. spowodowanie spadku utraty polskich majątków ziemskich w Prusach Zachodnich, o czym pisała redakcja pisma ${ }^{43}$.

Kwestię rolnictwa i propagowania działalności organizacji rolniczych oraz innych organizacji związanych z tą gałęzią gospodarki szerzej podjął chełmiński „Nadwiślanin” przeznaczony zasadniczo dla ludności wiejskiej. Sprawa zainteresowania ludności ideą towarzystw gospodarczych oraz edukacji rolniczej ludności wiejskiej były jedną z podstawowych kwestii poruszanych w pismach wychodzących w omawianym okresie w Prusach Zachodnich. Efektem zainteresowania „Nadwiślanina” ruchem towarzystw rolniczych były artykuły traktujące o konieczności zakładania tychże towarzystw w Prusach Zachodnich, jak i ogłoszenia zachęcające do udziału w zebraniach, co miało skupić wokół tej idei jak najszerszą grupę ludności ${ }^{4}$.

39 Ibidem, 172, 174. W 1876 do ZSZiG należało ogółem 27 spółek z Prus Zachodnich, zaś w 1890 działało ogółem 20 spółek pożyczkowych.

40 Ibidem, 172-174.

41 Ibidem, 173.

42 „Dlaczego to Polacy tak strasznie ubożeją”, Biedaczek 26 I 1850: 1-2.

43 Ibidem: 1.

44 Są to m.in. następujące artykuły: „Uwagi nad towarzystwem rolników polskich w Prusach Zachodnich utworzyć się mającem”, Nadwiślanin 23 X 1850: 1-2. Ciąg dalszy artykułu pod tym samym tytułem został zamieszczony [w:] Nadwiślanin 30 X 1850: 1-2 oraz 6 X 1850: 1-2; „Obwieszczenie”, Nadwiślanin 19 III 1851: 4 - ogłoszenie N. Sulerzyskiego z Piątkowa o zebraniu 25 III 1851 w Wąbrzeźnie w celu ułożenia statutów dla mającego powstać Towarzystwa Agronomów Polskich; Nadwiślanin 10 I 1862: 4 - ogłoszenie bez tytułu, apel o zebraniu 21 I 1862 w Chełmnie w sprawie zawiązania Towarzystwa Rolniczego na powiaty: chełmiński, toruński i grudziądzki; Nadwiślanin 10 I 1862: 4 - ogłoszenie bez tytułu, apel o zebraniu 21 I 1862 w Chełmnie w sprawie 


\section{Chełmiński „Przyjaciel Ludu” zamieszczał na swoich łamach ogłoszenia} dotyczące terminów zebrań organizacji rolniczych ${ }^{45}$. Przedstawianie tej tematyki na łamach pisma miało na celu m.in. popularyzację szerszego udziału ludności w pracach tych towarzystw.

W poszczególnych rocznikach „Przyjaciel Ludu” zamieszczał ogłoszenia informacyjne dotyczące zebrań m.in. następujących towarzystw rolniczych: Towarzystwa Agronomicznego dla Nowego Miasta ${ }^{46}$, Towarzystwa Agronomicznego w Chełmży ${ }^{47}$,

zawiązania Towarzystwa Rolniczego na powiaty: chełmiński, toruński i grudziądzki; „Uwiadomienia”, Nadwiślanin 31 I 1862: 4 - ogłoszenie o zgromadzeniu Towarzystwa Agronomicznego Sulęczyńskiego, które odbędzie się 17 II 1862 w Stężycy; „Korespondencya Nadwiślanina. Viribus Unitis”, Nadwiślanin 6 II 1862: 1-2; Nadwiślanin 8 III 1862: 4 - ogłoszenia zamieszczone w sprawie: mającego się odbyć 13 III 1862 zgromadzenia Towarzystwa Brodnicko-Lubawskiego w Brodnicy oraz zebrania w celu założenia Towarzystwa Agronomicznego dla Powiatów Kościerzyńskiego i Kartuskiego, mającego się odbyć 17 III 1862 w Kościerzynie; Nadwiślanin 1 IV 1862: 4 - ogłoszenie o zebraniu w celu założenia Towarzystwa Rolniczego Polskiego dla Powiatów Starogardzkiego i okolic 9 IV 1862 w Starogardzie; „Odezwa”, Nadwiślanin 20 V 1862: 6 - odezwa w sprawie zebrania w celu założenia Towarzystwa Rolniczego dla powiatów: świeckiego, chojnickiego, człuchowskiego, złotowskiego i wałeckiego 2 VI 1862 w Tucholi; informacja w sprawie posiedzenia polskiego Towarzystwa Agronomicznego powiatów: brodnickiego i lubawskiego, które miało się odbyć 5 VI 1862 w Nowym Mieście; Nadwiślanin 3 VI 1862: 3 - ogłoszenie w sprawie zebrania walnego zgromadzenia Towarzystwa Rolniczego Ziemi Chełmińskiej w Chełmży 5 VI 1862; Nadwiślanin 30 VIII 1862: 4 - ogłoszenie o zebraniu 11 IX 1862 w Brodnicy zgromadzenia Polskiego Towarzystwa Agronomicznego - podobne ogłoszenie w numerze 99 Nadwiślanina z 2 IX 1862: 4; „Kronika”, Nadwiślanin 17 I 1864: 4 - informacja o posiedzeniu Towarzystwa Rolniczego ziemi malborskiej 21 I 1864 w Postolinie; Nadwiślanin 14 II 1864: 4 - ogłoszenie w sprawie walnego zebrania Towarzystwa Rolniczego ziemi chełmińskiej 8 III 1864 w Radzynie; „Uwiadomienie”, Nadwiślanin 17 II 1864: 4 - dwa ogłoszenia w sprawie: zebrania 8 III 1864 w Radzynie Towarzystwa Rolniczego ziemi chełmińskiej oraz w sprawie zebrania Towarzystwa Rolniczego Ziemi Południowo-Pomorskiej w Tucholi 3 III 1864; Nadwiślanin 2 III 1864: 4 - ogłoszenie; „Uwiadomienie”, Nadwiślanin 18 III 1864: 4 - ogłoszenie o zebraniu walnego zgromadzenia Towarzystwa Rolniczego Powiatu Brodnickiego 31 III 1864 - nie podano, gdzie; Nadwiślanin 22 VI 1864: 4 - dwa ogłoszenia w sprawie: posiedzenia Towarzystwa Rolniczego Powiatu Gniewskiego w Piasecznie 13 VII 1864 oraz posiedzeniu Towarzystwa Rolniczego dla Ziemi Pomorskiej 6 VII 1864; „Nasze Towarzystwa”, Nadwiślanin 12 X 1864: 1; Nadwiślanin 16 X 1864: 1; Nadwiślanin 19 X 1864: 1; „Uwiadomienie”, Nadwiślanin 21 X 1864: 4 - ogłoszenie w sprawie: zebrania Towarzystwa Rolniczego Powiatu Gniewskiego w Piasecznie 16 XI 1864 oraz zebrania Towarzystwa Agronomicznego Powiatów: Brodnickiego i Lubawskiego w Brodnicy 3 XI 1864; „Uwiadomienie”; „Do członków Towarzystwa agronomicznego połączonych powiatów Brodnickiego i Lubawskiego”, Nadwiślanin 25 XI 1864: 4; „Odezwa”, Nadwiślanin 30 XII 1864: 4 - odezwa w sprawie zebrania Towarzystwa Rolniczego Ziemi Południowo-Pomorskiej w Drzycimiu w powiecie świeckim 10 I 1865 oraz ogłoszenie o zebraniu Towarzystwa Rolniczego Ziemi Pomorskiej 4 I 1865 w Starogardzie; „Uwiadomienie”, Nadwiślanin 28 IV 1865: 4 - ogłoszenie w sprawie zebrania Towarzystwa Rolniczego Ziemi Chełmińskiej 11 V 1865 w Chełmży; Nadwiślanin 20 VIII 1865: 4 - ogłoszenie w sprawie posiedzenia Towarzystwa Rolniczego powiatu gniewskiego w Piasecznie 13 IX 1865.

45 Np. Przyjaciel Ludu 23 V 1862: 4; Przyjaciel Ludu 6 VII 1867: 4; Przyjaciel Ludu 13 III 1868: 4; Przyjaciel Ludu 19 VI 1868: 4; Przyjaciel Ludu 5 II 1869: 4; Przyjaciel Ludu 27 V 1870: 3.

46 Przyjaciel Ludu 5 I 1872 - ogłoszenie o zebraniu 16 I 1872.

47 Przyjaciel Ludu 12 I 1872: 4 - ogłoszenie o zebraniu 17 I 1872. 
Towarzystwa Rolniczego w Skurczu ${ }^{48}$, Towarzystwa Rolniczego na Oksywiu ${ }^{49}$, towarzystw rolniczych w powiecie świeckim ${ }^{50}$, Towarzystwa Rolniczego w Pieniążkowie $^{51}$, Towarzystwa Rolniczego w Lisewie ${ }^{52}$, Towarzystwa Rolniczego Parafii Kwaszyńskiej ${ }^{53}$, Towarzystwa Rolniczego w Lucimiu ${ }^{54}$, Towarzystwa Rolniczego Okręgu Radzyńskiego ${ }^{55}$, Towarzystw Rolniczych Ziemi Południowo-Pomorskiej ${ }^{56}$, Towarzystwa Agronomicznego w Krotoszynie ${ }^{57}$, Kółka Rolniczego Mroteckiego ${ }^{58}$, Towarzystwa Rolniczego Powiatu Pleszewskiego i Odolanowskiego ${ }^{59}$, Towarzystwa Rolniczego Powiatu Inowrocławskiego ${ }^{60}$, Towarzystwa Rolniczego w Wilczu ${ }^{61}$, Towarzystwa Rolniczego w Ostrowie ${ }^{62}$, Towarzystwa Włościańskiego w Kcyni ${ }^{63}$, Towarzystwa Rolniczo-Przemysłowego w Chełmży ${ }^{64}$, Towarzystwo Przemysłowo-Rolniczego w Czarnkowie ${ }^{65}$, Towarzystwa Rolniczego w Górczynie ${ }^{66}$ i Towarzystwa Agronomicznego w Wielkich Śliwicach ${ }^{67}$.

„Przyjaciel Ludu” obok ogłoszeń o zebraniach towarzystw rolniczych zamieszczał także sprawozdania - relacje $\mathrm{z}$ ich działalności ${ }^{6}$. Typowe ogłoszenie informujące o zebraniu członków towarzystwa zawierało do kilku wierszy tekstu, zamieszczane było najczęściej na ostatniej lub przedostatniej stronie. Wśród ogłoszeń tych dominowały dotyczące towarzystw rolniczych, ukazywały się mniej więcej z tą samą częstotliwością na łamach „Nadwiślanina” i „Przyjaciela Ludu” (tylko w roku 1870 w „Przyjacielu Ludu” można zaobserwować minimalizację zamieszczania tego typu ogłoszeń, co wiązało się z wybuchem wojny

48 Ibidem - ogłoszenie o zebraniu tego towarzystwa 18 I 1872.

49 Przyjaciel Ludu 26 I 1872: 3 - ogłoszenie o zebraniu 8 II 1872.

50 Ibidem: 4 - ogłoszenie o zebraniach: 21 I 1872 (w Grucznie), 24 I 1872 (w Lubiewie), 28 I 1872 (w Drzycimiu).

${ }^{51}$ Przyjaciel Ludu 2 II 1872: 3 - ogłoszenie o uroczystości obchodzenia rocznicy założenia 6 II 1872.

52 Ibidem: 4 - ogłoszenie o posiedzeniach tego towarzystwa.

53 Przyjaciel Ludu 1 III 1872: 3 - ogłoszenie o zebraniu 2 IV 1872.

54 Ibidem: 4 - ogłoszenie o zebraniu 6 III 1872.

55 Przyjaciel Ludu 15 III 1872: 4 - ogłoszenie o zebraniu 17 III 1872.

56 Przyjaciel Ludu 17 V 1872: 3 - ogłoszenie o zebraniach w Śliwicach i Osiu 26 V 1872, Grucznie 2 VI 1872, Drzycimiu i Lubiewie 16 VI 1872.

57 Przyjaciel Ludu 7 VI 1872: 4 - ogłoszenie o zebraniu 18 VI 1872.

58 Ibidem - ogłoszenie o zebraniu 16 VI 1872.

59 Ibidem - ogłoszenie o zebraniu 17 VI 1872.

60 Ibidem - ogłoszenie o zebraniu 17 VI 1872.

${ }^{61}$ Przyjaciel Ludu 30 VIII 1872: 4 - ogłoszenie o zebraniu 4 IX 1872.

62 Przyjaciel Ludu 13 IX 1872: 4 - ogłoszenie o zebraniu 16 IX 1872.

${ }_{63}$ Przyjaciel Ludu 29 XI 1872: 4 - ogłoszenie o zebraniu 6 XII 1872.

${ }^{64}$ Przyjaciel Ludu 7 I 1876: 4 - ogłoszenie o zebraniu 11 I 1876.

65 Ibidem - ogłoszenie o zebraniu 9 I 1876.

66 Przyjaciel Ludu 11 II 1876: 4 - ogłoszenie o zebraniu 13 II 1876.

67 Przyjaciel Ludu 8 XII 1876: 4 - ogłoszenie o zebraniu 10 XII 1876.

68 Np. Przyjaciel Ludu 21 I 1876: 3 - sprawozdanie roczne z działalności Towarzystwa Rolniczego Lubiewia i okolicy - artykuł podpisano: „Ignacy Radkiewicz sekretarz”. 
francusko-pruskiej i w związku z tym chwilowym zarzuceniem wspomnianej tematyki).

Ubytek polskiej własności ziemskiej w Prusach Zachodnich dotyczył głównie obszarów o niższej kulturze rolnej ${ }^{69}$. Obszary natomiast o wysokiej kulturze rolnej znajdujące się m.in. na terenie powiatów toruńskiego i sztumskiego nie uległy w zasadzie większym zmianom własnościowym. Duży spadek polskiej własności ziemskiej zaznaczył się w powiecie lubawskim, a także w powiatach Pojezierza Pomorskiego - wyłączając powiaty tucholski i wejherowski ${ }^{70}$. Zaostrzenie walki o ziemię nastąpiło po 1886 r. - po uchwaleniu ustawy kolonizacyjnej i utworzeniu Komisji Kolonizacyjnej ${ }^{71}$.

Należy zauważyć, że ideę pracy organicznej z całą mocą zaczęto realizować po fiasku powstania styczniowego w zaborze rosyjskim. Odtąd zarzucenie walki zbrojnej, a skupienie się na pracy organicznej było właściwym myśleniem i kierunkiem polskich dążeń narodowych w drugiej połowie XIX w.

Kwestia wagi utrzymania ziemi w polskich rękach została podjęta szczególnie przez polskiego działacza narodowego z Prus Zachodnich - Ignacego Łyskowskiego $^{72}$. Na łamach „Przyjaciela Ludu” z 1863 r. przedstawił on swoje stanowisko w tej kwestii następująco:

Oj tak, polscy gospodarze, trzymajcie się waszej ziemi i waszego języka. Rolę macie po ojcach waszych, język polski od Boga. Pamięci więc ojców waszych i Bogu winniśmy to, abyśmy kochali nasz język, a ziemie ojczystą dzieciom naszym przekazali. W naszych stronach już się wszyscy poznali na tej prawdzie i jeden drugiego wspiera, - aby gospodarstwa w obce ręce nie puścić, lecz nawzajem się pouczać i dobrze gospodarować, aby pielęgnować w zagrodach polskich narodowość polską i wiarę, wstrzemięźliwość i wszystkie cnoty, które się Bogu podobają. I oto w tym celu są w naszych stronach pozakładane towarzystwa gospodarskie, do których należą włościańscy gospodarze, panowie i księża; na zgromadzeniach tego towarzystwa będą udzielane nauki i rady ${ }^{73}$.

69 Wajda, Przemiany w polskim stanie posiadania ziemi, 122.

70 Przyjaciel Ludu 21 I 1876: 3.

71 Jan Wróblewski, Polskie biblioteki ludowe w zaborze pruskim i na terenie Rzeszy Niemieckiej w latach 1843-1939 (Olsztyn: OBN im. Wojciecha Kętrzyńskiego, 1975), 21.

72 Łyskowski był autorem książek o tematyce gospodarczej, m.in.: Łyskowski, Gospodarz Prus Zachodnich czyli poradnik gospodarski dla pomniejszych właścicieli rolnych, cz. 1, O rolnictwie (Chełmno, 1851); idem, Rzecz o Towarzystwie Moralnych Interesów Ludności Polskiej pod Panowaniem Pruskim (Poznań: Mieczysław Leitgeber, 1869); idem, Trzy nauki gospodarskie (Warszawa: Gebethner i Wolff, 1883).

73 „Odpowiedź p. Ignacego Łyskowskiego na list poprzedni”, Przyjaciel Ludu 22 VIII 1863: 4 - list Łyskowskiego datowany jest na 27 VII 1863 - z Mileszew pod Jabłonowem. Apel Łyskowskiego miał pobudzić rozwój organizacji polskich - jak wiadomo w poprzedniej dekadzie, tj. w latach pięćdziesiątych XIX w., ich rozwój w Prusach Zachodnich był znacznie zahamowany, zob. Wierzchosławski, Polski ruch narodowy, 23. Program rozwoju gospodarczego zaproponowany przez Łyskowskiego przedstawił Wierzchosławski [w:] idem, Ignacy Łyskowski 1820-1886. Polityk i publicysta, pierwszy prezes Towarzystwa Naukowego $w$ Toruniu (Toruń: TNT, 2000). Oryginalne spojrzenie na zagadnienia gospodarcze prezentowane m.in. przez Łyskowskiego przedstawił Wierzchosławski [w:] idem, Orzeł czarny i orzeł biały. Problemy modernizacji społeczeństwa polskiego prowincji Prusy Zachodnie w XIX i na początku XX stulecia (Olsztyn: Littera, 2011), 56-60. 
Bardzo szeroko tematykę dotyczącą działalności organizacji rolniczych podjęła na swoich łamach „Gazeta Toruńska”. Poruszała ona ponadto tematykę gospodarczą poświęconą działalności różnego rodzaju organizacji rzemieślniczych, przemysłowych, a także instytucji finansowych - w tym pożyczkowych. Rolniczy charakter terenów Prus Zachodnich sprawiał, że siłą rzeczy największy nacisk został położony na rozwój organizacji agronomicznych; miało to także swoje uzasadnienie w dążeniu Polaków do utrzymania za wszelką cenę w swoich rękach ziem w dobie stopniowej ich utraty wskutek pruskiej polityki antypolskiej - szczególnie po $1886 \mathrm{r}$. Walka o ziemię polską urastała $\mathrm{w}$ tych warunkach do roli symbolu - a szczególna rola przypadła $w$ tej walce organizacjom rolniczym ${ }^{74}$. Rolę towarzystw rolniczych przedstawiono m.in. w artykule „Ruch Stowarzyszeń. Stowarzyszenia Prus Zachodnich”75.

Stałym elementem dotyczącym działalności organizacji rolniczych w Prusach Zachodnich były sprawozdania tych organizacji zamieszczane najczęściej w specjalnej rubryce pt. Ruch Stowarzyszeń lub Wiadomości miejscowe i prowincyonalne. Redakcja „Gazety Toruńskiej” drukowała sprawozdania z działalności organizacji rolniczych Prus Zachodnich: Towarzystwa Rolniczego Powiatu Lubawskiego ${ }^{76}$, Towarzystwa Rolniczego w Wąbrzeźnie ${ }^{77}$, Towarzystwa Rolniczego Powiatu Chełmińskiego ${ }^{78}$, Towarzystwa Rolniczego w Bobowie ${ }^{79}$, Towarzystwa Rolniczego w Piasecznie ${ }^{80}$, Towarzystwa Rolniczo-Przemysłowego Powiatu Toruńskiego ${ }^{81}$,

74 „Nasza posiadłość ziemska”, cz. 1, Gazeta Toruńska 13 XII 1872: 1-2; „Nasza posiadłość ziemska”, cz. 2, Gazeta Toruńska 14 XII 1872: 1-2; „Nasza posiadłość ziemska”, cz. 3, Gazeta Toruńska 15 XII 1872: 1-2; Jan Wróblewski, Polskie biblioteki ludowe w zaborze pruskim i na terenie Rzeszy Niemieckiej w latach 1843-1939 (Olsztyn: OBN im. Wojciecha Kętrzyńskiego, 1975), 21.

75 „Ruch Stowarzyszeń. Stowarzyszenia Prus Zachodnich”, Gazeta Toruńska 8 III 1867: 2 - „Główna uwaga towarzystw naszych rolniczych zwrócona jest naturalnie na rolnictwo i postępowe gospodarstwo. Sprawozdania z pierwszych dwóch miesięcy roku tego wykazują szczególnie staranie o podniesienie sił roboczych przez polepszanie inwentarza i powiększanie dochodów bieżących z chowu bydła. Również rozpowszechnianie gospodarstwa płodozmiennego i poprawnych narzędzi gospodarskich agitowano jak najgoręcej. Przytem dążąc za ułatwieniem koniecznych nakładów, zakupują towarzystwa ryczałtem, a więc taniej, nasiona gospodarskie i sól bydlęcą do rozdziału między członków. Niektóre posunęły działalność swą w tym względzie jeszcze dalej przez hurtowe zakupywanie produktów dla domowego użytku członków, jako to kawy, cukru, mydła itp. są to związki towarzystw konsumpcyjnych [...]. Towarzystwa rolnicze są nad to wszystko jeszcze organem szerzenia oświaty. [...] Do towarzystw włościańskich wstępują oprócz włościan i mniejszych właścicieli także właściciele więksi, łączący z majątkiem większym i większy zasób intelligencyi”.

76 „Ruch Stowarzyszeń”, Gazeta Toruńska 19 I 1867: 3; „Ruch Stowarzyszeń”, Gazeta Toruńska 8 VI 1867: 3; „Wiadomości miejscowe i prowincyonalne”, Gazeta Toruńska 29 X 1867: 2.

77 „Ruch Stowarzyszeń”, Gazeta Toruńska 14 III 1867: 2-3; „Ruch Stowarzyszeń”, Gazeta Toruńska 31 III 1867: 2; „Ruch Stowarzyszeń”, Gazeta Toruńska 24 IV 1867: 2.

78 „Ruch Stowarzyszeń”, Gazeta Toruńska 20 III 1867: 3.

79 „Ruch Stowarzyszeń”, Gazeta Toruńska 30 III 1867: 2.

80 „Ruch Stowarzyszeń”, Gazeta Toruńska 2 IV 1867: 2; „Wiadomości miejscowe i prowincyonalne", Gazeta Toruńska 20 X 1870: 3.

81 „Wiadomości miejscowe i prowincyonalne”, Gazeta Toruńska 7 IV 1867: 3; „Ruch Stowarzyszeń”, Gazeta Toruńska 7 V 1867: 2-3; „Ruch Stowarzysze”, Gazeta Toruńska 4 X 1867: 2; „Wiadomości miejscowe i prowincyonalne. Toruń, 11 stycznia”, Gazeta Toruńska 12 I 1873: 3. 
Towarzystwa Rolniczego w Pieniążkowie ${ }^{82}$, Towarzystwa Gospodarczego Pelplińskiego ${ }^{83}$, Towarzystwa Rolniczego Powiatu Brodnickiego ${ }^{84}$, Towarzystwa Agronomicznego Ziemi Południowo-Pomorskiej w Czersku ${ }^{85}$, Towarzystwa Rolniczego w Dużym Pułkowie ${ }^{86}$, Towarzystwa Rolniczego w Łasinie ${ }^{87}$, Towarzystwa Rolniczo-Przemysłowego w Chełmży ${ }^{88}$, Towarzystwa Rolniczego w Radzyniu ${ }^{89}$, Towarzystwa Rolniczo-Przemysłowo-Politycznego w Wąbrzeźnie ${ }^{90}$, Towarzystwo Rolniczego w Chełmży ${ }^{91}$, Kółka Rolniczego w Nowym Mieście ${ }^{92}$, Towarzystwa Rolniczego dla Kowalewa i okolicy ${ }^{93}$, Towarzystwa Rolniczo-Włościańskiego w Góralach ${ }^{94}$, Towarzystwa Rolniczego w Papowie Biskupim ${ }^{95}$, Towarzystwa Rolniczo-Przemysłowego na okolicę Łobżenicy ${ }^{96}$, Kółka Rolniczego w Pniewach ${ }^{97}$, Towarzystwa Rolniczego dla okolicy Gruczyńskiej ${ }^{98}$, Kółka Rolniczego w Osiu ${ }^{99}$, Towarzystwa Rolniczego na Parafię Mechowską i okolice ${ }^{100}$, Towarzystwa Rolniczego w Radzyniu ${ }^{101}$, Towarzystwa Rolniczego w Lubiewie ${ }^{102}$ i Towarzystwa Agronomicznego w Suszu ${ }^{103}$.

Sytuacja polityczna, jaka nastąpiła po roku 1871 - tj. po utworzeniu II Rzeszy Niemieckiej, przejawiająca się w polityce wewnętrznej w Prusach Zachodnich restrykcyjnym ustawodawstwem Kulturkampfu, ściślejszą niż dotychczas kontrolą

\footnotetext{
82 „Ruch Stowarzyszeń”, Gazeta Toruńska 10 IV 1867: 3.

83 „Ruch Stowarzyszeń”, Gazeta Toruńska 25 IV 1867: 2.

84 „Ruch Stowarzyszeń”, Gazeta Toruńska 27 VI 1867: 2-3.

85 „Ruch stowarzyszeń”, Gazeta Toruńska 4 VII 1867: 3.

86 „Wiadomości miejscowe i prowincyonalne”, Gazeta Toruńska 4 III 1868: 3.

87 „Wiadomości miejscowe i prowincjonalne”, Gazeta Toruńska 3 XI 1868: 3; „Wiadomości miejscowe i prowincyonalne", Gazeta Toruńska 4 XII 1868: 3.

88 „Wiadomości miejscowe i prowincyonalne”, Gazeta Toruńska 9 IV 1869: 3; „Wiadomości miejscowe i prowincyonalne. Toruń, 30 czerwca”, Gazeta Toruńska 1 VII 1873: 4.

89 „Wiadomości miejscowe i prowincyonalne”, Gazeta Toruńska 30 X 1869: 2-3.

90 „Wiadomości miejscowe i prowincyonalne”, Gazeta Toruńska 16 I 1872: 3; „Wiadomości miejscowe i prowincyonalne”, Gazeta Toruńska 7 VIII 1872: 3.

91 „Wiadomości miejscowe i prowincyonalne”, Gazeta Toruńska 28 I 1873: 3-4.

92 „Wiadomości miejscowe i prowincyonalne. Toruń, 11 marca”, Gazeta Toruńska 12 III 1873: 3.

93 „Wiadomości miejscowe i prowincyonalne. Toruń, 21 czerwca”, Gazeta Toruńska 22 VI 1873: 3.

94 „Wiadomości miejscowe i prowincyonalne. Toruń, 1 kwietnia”, Gazeta Toruńska 2 IV 1874: 4.

95 „Wiadomości miejscowe i prowincyonalne. Toruń, 23 listopada”, Gazeta Toruńska 24 XI
} 1874: 3-4.

96 „Wiadomości miejscowe i prowincyonalne. Toruń, 11 lutego”, Gazeta Toruńska 12 II 1875: 4; „Wiadomości miejscowe i prowincyonalne. Toruń, 15 marca”, Gazeta Toruńska 16 III 1875: 6.

97 „Wiadomości miejscowe i prowincyonalne. Toruń, 26 lutego”, Gazeta Toruńska 27 II 1875: 4.

98 Ibidem - redakcja poinformowała, że w powiecie świeckim istnieje pięć towarzystw rolniczych: w Drzycimiu, Grucznie, Lubiejewie, Błądzimiu i Sierocku. Szóste zaś zostanie prawdopodobnie założone w Osiu.

99 „Wiadomości miejscowe i prowincyonalne. Toruń, 4 marca”, Gazeta Toruńska 5 III 1875: 4.

100 „Wiadomości miejscowe i prowincyonalne. Torun, 11 listopada”, Gazeta Toruńska 12 XI 1875: 4.

101 „Korespondencye Gazety Toruńskiej. Radzyń, 10 stycznia”, Gazeta Toruńska 13 I 1876: 1.

102 „Korespondencye Gazety Toruńskiej”, Gazeta Toruńska 25 V 1877: 1-2.

103 „Wiadomości potoczne”, Gazeta Toruńska 26 VIII 1880: 4. 
prasy i organizacji, spowodowała zahamowanie aktywności w działalności polskich organizacji rolniczych. Urzędnikiem pełniącym funkcje kontrolne w okresie po $1871 \mathrm{r}$. wobec organizacji polskich w Prusach Zachodnich był komisarz policji pruskiej - Rex ${ }^{104}$. Jego działalność w tym zakresie polegająca na uczestnictwie w zebraniach towarzystw rolniczych doprowadziła do ogromnego spadku frekwencji podczas tych spotkań. W tej sytuacji oprócz zebrań jawnych polskich organizacji rolniczych odbywały się także spotkania nieoficjalne ${ }^{105}$. Strona polska, chcąc podnieść frekwencję na zebraniach organizacji rolniczych, doprowadziła w niektórych przypadkach do ich połączenia - reorganizacje te nie odnosiły jednak w pełni zamierzonego celu ${ }^{106}$.

Organizacje rolnicze propagujące prace organiczne, w swoich programach i statutach stawiały na rozwój stanu włościańskiego poprzez oświatę rolniczą (zwrócenie głównej uwagi na propagowanie płodozmianu) i pielęgnowanie języka polskiego. W związku z tym działalność dotycząca rozwoju organizacji rolniczych łączyła się często z obroną polskich praw językowych. Wiązało się to $\mathrm{z}$ faktem, że rozwój ruchu towarzystw rolniczych oznaczał także kultywowanie języka polskiego, którego używanie w dobie rządów kanclerza Otto Bismarcka było w znacznym stopniu ograniczone. Tym samym uważano, że nie należy dążyć np. do łączenia analogicznych towarzystw rolniczych polskich i niemieckich, gdyż oznaczałoby to w perspektywie zmniejszanie się wpływów języka polskiego. Taka sytuacja została przedstawiona w artykule Połaczenie towarzystw rolniczych ${ }^{107}$. „Gazeta Toruńska” przy okazji polemiki nad projektem połączenia towarzystw rolniczych niemieckich z polskimi w Wielkim Księstwie Poznańskim stanęła zdecydowanie na stanowisku obrony polskich praw językowych ${ }^{108}$.

Część artykułów poświęconych działalności organizacji rolniczych w Prusach Zachodnich dotyczyła analizy kryzysu ich funkcjonowania ${ }^{109}$.

104 Bukowski, Juliusz Kraziewicz, 66-67 - do zadań Rexa należała także kontrola polskich czytelni oraz wydawnictw.

105 Ibidem, 67.

106 Ibidem, 67-68 - tak było np. w przypadku Kółka Rolniczego w Piasecznie i Pieniążkowie, które to połączono w XI 1877 w jedno towarzystwo pod nazwą: Towarzystwo Rolnicze dla Powiatu Kwidzyńskiego. Siedzibą tego towarzystwa było Piaseczno.

107 „Połączenie towarzystw rolniczych”, Gazeta Toruńska 30 XI 1876: 1-2 - „Zostawcie Polakom przecież to jedno przynajmniej, iżby między sobą, w swoich stowarzyszeniach z dobrej woli zawartych mówili z tą swobodą, której wy doznajecie wszędzie".

108 Ibidem; Przemysław Hauser, Kolonista niemiecki w XIX i XX wieku. Mity i rzeczywistość (Poznań: Wydawnictwo Naukowe Uniwersytetu Adama Mickiewicza, 1994).

109 Np. „Kółka rolnicze”, Gazeta Toruńska 1 XII 1876: 1-2 - spośród przyczyn zastoju w rozwoju kółek rolniczych w Prusach Zachodnich „Gazeta Toruńska” wymieniła m.in. niewłaściwą pracę kierownictwa poszczególnych towarzystw oraz „zawiedzione nadzieje”, co przejawiało się w zbyt dużych obietnicach przy zakładaniu towarzystw rolniczych; „Kółka rolnicze”, Gazeta Toruńska 5 XII 1876: 1-2. W artykule tym będącym dalszym cyklem artykułu z numeru 278 z 1876 podała „Gazeta Toruńska” rady mające uzdrowić i uaktywnić funkcjonowanie kółek rolniczych. 
Tygodnik „Piast”, podobnie jak i inne specjalistyczne czasopisma Prus Zachodnich poświęcone tematyce rolniczo-gospodarczej, wskazywał na ogromne znaczenie roli towarzystw rolniczych w walce o postęp w dziedzinie gospodarczej, a tym samym umożliwieniu narodowi polskiemu osiągnięcia wyższych standardów materialnych i moralnych. Informacje służące działalności towarzystw rolniczych (m.in. daty zebrań, rocznic powstania itd.), a także zawiązania się nowych najczęściej były przedstawiane w specjalnej rubryce pt. Kalendarz Towarzystw $w^{110}$. Ważne funkcje w krzewieniu oświaty rolniczej redakcja „Piasta” przypisywała uczestnictwu w wystawach rolniczych ${ }^{111}$. Wyrazem zainteresowania redakcji sprawami działalności towarzystw rolniczych były zamieszczane na łamach pisma sprawozdania z zebrań towarzystw rolniczych ${ }^{112}$. Tematyka dotycząca działalności tych towarzystw zajmowała drugie miejsce pod względem objętości artykułów drukowanych na łamach „Piasta”. Przykładowo o roli towarzystw rolniczych wspominał znany pionier polskich organizacji rolniczych, Kraziewicz, następująco:

[...] potęga stowarzyszeń jest cudowna. Trzeba tylko spólnej pracy i zaufania. Tak, bracia kochani, spólna praca i zaufanie są to filary wszystkich w świecie społeczeństw, a bez nich każde stowarzyszenie musi się rozchwiać. Jeżeli nie chcemy zguby naszych towarzystw, to pracujmy spólnie, szczerze i wytrwale, a z pewnością nie odmówi nam Bóg Swej pomocy i błogosławieństwa ${ }^{113}$.

110 Np. „Kalendarz Towarzystw”, Piast 17 I 1867: 8 - „Pod powyższą rubryką będziemy w Piaście umieszczali uwiadomienia o zebraniach towarzystw bezpłatnie, gdyż tylko literackie obwieszczenia płatne wolno nam umieszczać.

D. 20 stycznia w niedzielę odbędzie zebranie Spółka Pożyczkowa w Golubiu, Spółka Brodnicka u ob. Czarnowskiego i okręgowe Towarzystwo Rolnicze w Drzycimiu.

D. 21 stycznia w poniedziałek Towarzystwo Rolnicze ziemi Malborskiej w Pierzchowicach u ob. Hartmana o 2giej po południu. Dla obioru nowego prezesa i założenia Spółki Pożyczkowej prosi się o liczny udział.

D. 22 stycznia Spółka Pożyczkowa miasta Chełmna o 7 wieczorem w hotelu rzymskim. Dla ważnych powodów uprasza zarząd o liczny udział.

D. 23 stycznia Spółka Pożyczkowa w Chełmży u ob. Kiełpińskiego o 10 rano. Uprasza się o liczny udział tak członków jak i życzliwych rodaków, pragnących się zapisać na członków”; Bukowski, Juliusz Kraziewicz, 46-47.

111 Np. „Zachęta do udziału w wystawach rolniczych”, Piast 4 VIII 1868: 1-2.

112 Np. „Sprawozdanie z posiedzenia Towarzystwa Rolniczego w Piasecznie, odbytego d. 12 grudnia 1866”, Piast 10 I 1867: 7-8; „Sprawozdanie z posiedzenia Towarzystwa Rolniczego ziemi Malborskiej w Podstolinie dnia 27 grudnia 1866 r.”, Piast 17 I 1867: 7-8; „Sprawozdanie z posiedzenia towarzystwa Rolniczego, odbytego w Pieniążkowie dnia 2 stycznia 1867”, Piast 24 I 1867: 14; „Sprawozdanie z posiedzenia Towarzystwa rolniczo-przemysłowego dla powiatu Toruńskiego, odbytego w Chełmży dnia 23 lutego 1867”, Piast 14 III 1867: 6-8; „Sprawozdanie z posiedzenia Towarzystwa rolniczego w Wąbrzeźnie dnia 29 marca rb.", Piast 4 IV 1867: 7; „Sprawozdanie z posiedzenia Towarzystwa Rolniczego Ziemi Kaszubskiej ptu Kościerzyńskiego”, Piast 9 V 1867: 7-8; „Jeneralne Sprawozdanie z czynności Dolskiego Kółka Włościańsko Rolniczego na rok 1867”, Piast 26 II 1868: 3-6; „Sprawozdanie z posiedzenia Tow. Roln. powiatu Lubawskiego”, Piast 22 IV 1868: 7; „Sprawozdanie z posiedzenia Tow. Rolniczego w Nakle odbytego d. 6 Maja rb.”, Piast 1 IX 1868: 8.

113 „Potęga stowarzyszeń”, Piast 10 I 1867: 3. 
Kwestie gospodarcze - w tym rolnictwa i organizacji rolniczych - były stosunkowo rzadko podejmowane na łamach wychodzącego w Pelplinie „Pielgrzyma”. W rocznikach 1869-1890 „Pielgrzym” zamieszczał najczęściej działalność następujących organizacji rolniczych Prus Zachodnich: towarzystw rolniczych powiatu świeckiego ${ }^{114}$, Towarzystwa Rolniczego w Kościerzynie ${ }^{115}$, Towarzystwa Rolniczego na Mechowo i okolice ${ }^{116}$, Towarzystwa Rolniczego w Śliwicach ${ }^{117}$, Towarzystwa Rolniczego w Tucholi ${ }^{118}$, Towarzystwa Rolniczego w Raciążu ${ }^{119}$, Towarzystwa Rolniczego w Piasecznie ${ }^{120}$ i Towarzystwa Agronomicznego na Barłożno i okolicę ${ }^{121}$.

"Pielgrzym” doceniał jednak rolę i znaczenie towarzystw gospodarczych - w tym rolniczych - spełniających nie tylko funkcję gospodarczą. Wyrazem tego był m.in. artykuł Potrzeby Towarzystw Ludowych ${ }^{122}$, w którym redakcja gorąco zachęcała do zakładania nowych towarzystw ${ }^{123}$.

Pismem adresowanym do rolników był wychodzący także w Pelplinie „Rolnik". Cykl artykułów traktujących o praktycznym wpływie towarzystw rolniczych w Prusach Zachodnich na rozwój gospodarstw włościańskich został zamieszczony w odnośnych numerach pisma z 1869 r. Redakcja cytowała w poszczególnych artykułach rozprawę majora Stanisława Radkiewicza, odczytaną przez niego na Sejmiku Gospodarskim w Toruniu 22 lutego 1869 r., której tytuł brzmiał O stanie gospodarstw włościańskich $w$ Prusach Zachodnich i o wplywie towarzystw rolniczych, jaki na poprawę tychże wywarly przez Majora Radkiewicza z Brzeźna ${ }^{124}$ [powiat świecki - K.S.]. Wpływ działalności towarzystw rolniczych w Prusach Zachodnich na rozwój gospodarstw został scharakteryzowany przez owego działacza narodowego następująco:

Dla gruntownego zbadania wyprosiłem sobie od [...] znanych Towarzystw rolniczych w Prusach Zachodnich wykazy szczegółów dotyczących gospodarstw włościańskich, z których wykazuje się, że w wszystkich prawie, w jednych więcej w drugich mniej, już pozaprowadzane są u włościan za pośrednictwem towarzystw

114 Pielgrzym nr 2 z I (nie podano dnia stycznia) 1875: 8 - ogłoszenie o zebraniu organizacji rolniczych powiatu świeckiego.

115 Pielgrzym 1 II 1876: 4 - ogłoszenie o zebraniu Towarzystwa Rolniczego w Kościerzynie 10 II 1876.

116 Pielgrzym 9 III 1876: 2 - ogłoszenie o zebraniu Towarzystwa Rolniczego na Mechowo i okolicę 16 III 1876.

117 Ibidem - ogłoszenie o zebraniu Towarzystwa Rolniczego w Śliwicach.

118 Ibidem - ogłoszenie o zebraniu Towarzystwa Rolniczego w Tucholi.

119 Ibidem - ogłoszenie o zebraniu Towarzystwa Rolniczego w Raciążu.

120 Pielgrzym 5 X 1876: 2 - ogłoszenie o zebraniu towarzystwa 11 X 1876.

121 Pielgrzym 22 III 1884: 4 - ogłoszenie o zebraniu towarzystwa 27 III 1884.

122 „Potrzeby Towarzystw Ludowych”, Pielgrzym 26 X 1876: 1.

123 Ibidem: 1; E. Piszcz, „Stulecie „Pielgrzyma”, Studia Pelplińskie 1 (1969): 203-206; Romanow, „Pielgrzym” pelpliński w latach 1869-1920, 85.

124 „O stanie gospodarstw włościańskich w Prusach Zachodnich i o wpływie towarzystw rolniczych, jaki na poprawę tychże wywarły, przez Majora Radkiewicza z Brzeźna”, Rolnik 5 III 1869: 2-5. 
rolniczych gospodarstwa płodozmienne. Co się zaś dotyczy zakładania lucerników, siania koniczyn, roślin pastewnych i okopowych, to także w wszystkich Towarzystwach rolniczych znaczny już postęp uczyniły, z czego wnosić można, że z tym postępem i przejście w gospodarstwa płodozmienne, które jest kwintesencją zadania Towarzystw rolniczych koniecznie coraz więcej nastąpi ${ }^{125}$.

Redakcja „Rolnika” podejmowała także kwestie dotyczące barier w rozwoju polskich gospodarstw włościańskich w Prusach Zachodnich ${ }^{126}$. Według niej jedną $\mathrm{z}$ istotnych barier stojących na przeszkodzie ku dalszemu rozwojowi stał m.in. konserwatyzm rolnika polskiego patrzącego niechętnie na wszelkiego rodzaju nowiny techniczne i opierającego się ich zastosowaniu ${ }^{127}$. Według redakcji była to jedna $\mathrm{z}$ istotniejszych barier stojących na przeszkodzie ku dalszemu rozwojowi mającemu sprostać konkurencji strony niemieckiej. Redakcja „Rolnika” podała także inne według niej przyczyny niepowodzeń w tym względzie. Chodziło o niekorzystne cechy rolnika polskiego, takie jak niechęć do aktywizmu czy niedbalstwo. Były to właściwości, które według redakcji bardzo rzadko można znaleźć u gospodarza niemieckiego ${ }^{128}$.

Tygodnik „Rolnik” w zasadzie sporadycznie zamieszczał w roczniku 1869 artykuły poświęcone działalności organizacji rolniczych istniejących w Prusach Zachodnich. Artykuły te dotyczyły głównie sprawozdań następujących towarzystw rolniczych: ze Skurcza $^{129}$, z Bobowa ${ }^{130}$, z powiatu kościerskiego ${ }^{131}$, z Kowalewa ${ }^{132}$ i z Tucholi ${ }^{133}$. Zamieszczono także artykuły (pięć) dotyczące relacji z przebiegu III Sejmiku Gospodarskiego, który odbył się 22 i 23 lutego 1869 r. w Toruniu i był poświęcony sprawom rolnictwa ${ }^{134}$.

\section{Ibidem: 3.}

126 „Co stoi na przeszkodzie ogólnemu rozwojowi i podniesieniu gospodarstw naszych włościańskich?”, Rolnik 1 X 1869: 1-2 - artykuł podpisano inicjałami: J.M.

127 „Co stoi na przeszkodzie”: 2. Stosunek rolnika do wszelkich nowości redakcja scharakteryzowała następująco: „At co tam po tych włościach. Mój ojciec, dziad i pradziad tak gospodarowali i ja tak gospodarować będę; im z tem dobrze było i mnie tem będzie dobrze".

${ }_{128}$ „Co stoi na przeszkodzie”: 2 - „Często też nie tylko taki upór i zastarzałość pojęć, ale i niechęć i niedbalstwo są przyczynami, o które najlepsze nieraz chęci się rozbijają. Oto są znowu z drugiej strony przyczyny (naturalnie też z wyjątkami), dla czego u nas tak nie jest, jak w oświeceńszych nam Niemczech".

129 „Sprawozdanie z walnego zebrania Towarzystwa Rolniczego w Skurczu z dnia 4 stycznia 1869 r.", Dodatek do: Rolnik 8 I 1869: 5.

130 Ibidem: 5-6.

131 „Sprawozdanie Towarzystwa Rolniczego pt. Kościerskiego z odbytych zebrań okręgowych dnia 13 października 1868 we Wysinie i dnia 19 października 1868 w Kiszewie”, Dodatek do: Rolnik 8 I 1869: 6.

132 „Sprawozdanie z zebrania Towarzystwa Rolniczego w Kowalewie”, Rolnik 15 I 1869: 4.

133 „Sprawozdanie z odbytego posiedzenia rolniczego w Tucholi”, Rolnik 19 XI 1869: 3-4.

134 Były to następujące artykuły: „Sejmik gospodarski”, Rolnik 12 II 1869: 1; „Trzeci sejmik gospodarski”, Rolnik 12 II 1869: 1-2; „Trzeci sejmik gospodarski”, Rolnik 26 II 1869: 1-2; „Trzeci sejmik gospodarski”, Rolnik 5 III 1869: 1-2; „Trzeci sejmik gospodarski”, Rolnik 12 III 1869: 1-2 (podpisano J.M.). 
Odnośnie do organizacji rolniczych redakcja „Rolnika” zamieszczała ponadto ogłoszenia informacyjne o terminach ich zebrann ${ }^{135}$.

Pismem przeznaczonym dla rolników był toruński „Gospodarz”. Artykuły poświęcone działalności towarzystw rolniczych w Prusach Zachodnich zajęły pod względem objętości drugie miejsce na łamach toruńskiego „Gospodarza”, po artykułach dotyczących szeroko rozumianego poradnictwa gospodarczego ${ }^{136}$. Redakcja zwracała także uwagę na konieczność ściślejszej integracji i współpracy między gospodarzami ${ }^{137}$.

Uznanie dużej roli organizacji rolniczych $\mathrm{w}$ dziele rozwoju materialnego społeczeństwa polskiego przez redakcję „Gospodarza” nie oznaczało biernej i bezkrytycznej akceptacji wszystkich inicjatyw tych stowarzyszeń. W ramach swoich głosów krytycznych wobec działalności tych organizacji rolniczych redakcja wskazywała na zbytnią bierność, apelując zarazem do aktywniejszej działalności ${ }^{138}$. Podkreślała niską frekwencję i nieregularność udziału członków w zebraniach

135 Np. „Ogłoszenia”, Rolnik 22 I 1869: 4; „Ogłoszenie o walnym zebraniu Towarzystwa Rolniczego Bobowskiego i Skurczewskiego Członków towarzystwa rolniczego”, Rolnik 19 III 1869: 4; „Ogłoszenie o zebraniu członków Towarzystwa Rolniczego Powiatu Kościerskiego”, Rolnik 2 VII 1869: 4.

136 „Kilka słów o towarzystwach rolniczych”, Gospodarz 23 XI 1871: 1. Rolę i zadania towarzystw rolniczych „Gospodarz” przedstawił we wspomnianym artykule następująco: „[...] środkiem kształcenia się są tak gęsto pomiędzy nami związane Towarzystwa Rolnicze. Masz czas kochany bracie, uczęszczaj więc regularnie na zebrania, bo to dobra szkoła. Nie uczą tu już abecadła, ale pouczają się wzajemnie ludzie dojrzali, czerpiąc naukę z życia i swoich doświadczeń. Mówią z życia, a mam na myśli życie, czyli ruch gospodarczy, jaki się toczy na około nas, lub w dalszych od nas stronach. [...] Nauka zatem na zebraniach, gdzie licznie i z zajęciem zasiadają członkowie, gdzie każdy dobre uważa i zastanawia się nad tem, co tu mówią, lub sam swoje doświadczenia wypowiada, niepośledni może wywrzeć wpływ na gospodarstwa nasze. Byłby to więc wpływ towarzystw rolniczych na naukę gospodarstwa, a pośrednio na podniesienie się naszych gospodarstw. Lecz towarzystwa nasze winne, przy gorliwości członków, także bezpośrednio zaraz wpłynąć na polepszenie gospodarstw naszych [...]”.

137 „Kilka słów o towarzystwach rolniczych”, Gospodarz 23 XI 1871: 2 - „Z kilku tych uwag uznać musimy, że łączność zwłaszcza między nami małymi gospodarzami, bardzo może wpłynąć na podniesienie gospodarstw naszych. Lecz potrzeba nam koniecznie więcej zainteresowania, więcej musimy myśleć o tem dlaczego gospodarstwa nasze kuleją, potrzeby nasze, jeśli im sami zadość uczynić nie możemy, objawiać na zebraniach, a może wspólne siły im zaradzić potrafią. [...] Pamiętajmy więc, bracia gospodarze, zwłaszcza my na małych gospodarstwach, że dla nas nader ważne jest zdanie »wspólna tylko moc zdoła nas ocalićc"”.

138 „Słówko Gospodarza do Towarzystw rolniczych”, Gospodarz 10 X 1872: 1 - „Zakładając pismo nasze sądziliśmy, że główne poparcie i pomoc znajdziemy w towarzystwach rolniczych, tak licznie u nas rozgałęzionych. Sądziliśmy, że z nimi ręka w rękę pracować będziemy, odbierając od nich wskazówki czego brak w gospodarstwach naszych, a więc o czem Gospodarz najwięcej pisać powinien. Dla tego to ustanowiliśmy dział pytań, sądząc, że z niego tę korzyść osiągniemy, iż się dowiemy o potrzebach naszych gospodarzy. Dzisiaj pozostaliśmy nieledwie osamotnieni w pracy i z tego powodu odzywamy się do towarzystw rolniczych - rozbudźcie się! - rozpatrujcie się w czem kuleją gospodarstwa waszych okolic, donoście nam, jaki jest powód, iż się podnieść nie mogą, a będziemy się starali w piśmie naszem wytykać błędy i radzić nad ich usunięciem”. Cykl artykułów o podobnej wymowie podkreślających pewne wady w działalności kółek rolniczych znajduje się m.in. w: „Niektóre uwagi nad rozwojem naszych rolniczo-włościańskich Kółek i pogląd 
organizacji rolniczych jako główne bariery hamujące skuteczny rozwój tych stowarzyszeń ${ }^{139}$. Zarzucała także niektórym towarzystwom poważne braki i chaos organizacyjny, co miało wyraz w przebiegu samych obrad ${ }^{140}$.

Stałym tematem dotyczącym działalności organizacji rolniczych w Prusach Zachodnich na łamach Gospodarza były relacje ze sprawozdań tych towarzystw, przedstawiane najczęściej w specjalnej rubryce Sprawozdania $z$ towarzystw rolniczych oraz Listy do „Gospodarza”"14. „Gospodarz” zamieszczał również informacje dotyczące terminów mających się odbyć zebrań towarzystw rolniczych. Informacje te lokowano w specjalnej rubryce pt. Kalendarzyk zebrań ${ }^{142}$ (bardzo często do 1887 r.), znajdującej się na ostatniej stronie pisma.

na wynikające stąd korzyści”, Gospodarz 11 VIII 1881: 1-2 - i cd.: artykuły pod tym samym tytułem w: Gospodarz 18 VIII 1881: 1-2; Gospodarz 5 VIII 1881: 1-2.

139 Np. „Do członków kółka włościańskiego Kłeckiego”, Gospodarz 29 VII 1875: 5-6 - artykuł podpisany został przez M. Jackowskiego - patrona kółek rolniczych włościańskich; „Do kółka rolniczego w Buku”, Gospodarz 9 XII 1875: 1-2 - autorem tego artykułu był także Jackowski; w artykule pt. „Jakie są powody nieuczęszczania gospodarzy naszych na zgromadzenia rolnicze?”, Gospodarz 23 IX 1875: 1-2 (podpisanym: A.K. - z okolic Lubawy) - przedstawiono główne przyczyny niskiej frekwencji na posiedzeniach związków rolniczych, do których autor zaliczył: lekceważenie nauki fachowej, brak wzajemnego zaufania członków towarzystwa, zarozumiałość przejawiająca się w ignorancji i przekonaniu o przewadze własnej wiedzy rolniczej nad tą prezentowaną na zebraniach.

140 „Słówko Gospodarza do zarządu kółek i towarzystw rolniczych”, Gospodarz 11 XI 1875: 1-2 redakcja podała, że przyczyna tego stanu rzeczy jest m.in. następująca: „Mianowicie przewodniczących z stanu włościańskiego słyszeliśmy się żalących, że skoro ktoś z większych gospodarzy, dziedziców, rządców, jednym słowem inteligentniejszych rolników na zebrania nie przybędzie, to im trudno sobie dać radę, bo nie ma kogo, coby naprawdę rozpoczął [...]”. Redakcja dała w celu zaradzenia temu stanowi rzeczy następującą radę: „Otóż takim panom zwracamy uwagę na Gospodarza [...]. Gdyby więc sam przewodniczący wziął przed każdym zebraniem, na które właśnie niemiałby nic lepszego, ostatnie numery »Gospodarza« w rękę i przejrzał zawarte w nim artykuły, pewnieby tam jeden lub dwa znalazł, które głośno i powoli przeczytane, podały by materyał do dyskusyi [...]”.

141 Np. „Sprawozdanie z towarzystw rolniczych”, Gospodarz 2 XI 1871: 4; „Sprawozdanie z towarzystw rolniczych”, Gospodarz 23 XI 1871: 4; „Sprawozdania towarzystw”, Gospodarz 21 XII 1871: 4; „Sprawozdania urzędowe zgromadzenia Towarzystwa rolniczo-przemysłowo-politycznego”, Gospodarz 18 I 1872: 3; „Sprawozdanie Towarzystw”, Gospodarz 25 I 1872: 4; „Listy do Gospodarza”, Gospodarz 10 X 1872: 4; „Listy do Gospodarza”, Gospodarz 2 I 1873: 3-4; „Sprawozdania Towarzystw rolniczych”, Gospodarz 6 II 1873: 4; „Sprawozdania towarzystw rolniczych”, Gospodarz 7 V 1874: 3; „Serock, 14 lutego”, Gospodarz 25 II 1875: 3-4; „Listy do Gospodarza”, Gospodarz 11 III 1875: 3; „Listy do Gospodarza”, Gospodarz 18 III 1875: 4; „Sprawozdania towarzystw rolniczych”, Gospodarz 27 V 1875: 4; „Listy do Gospodarza”, Gospodarz 24 III 1881: 2-3; „Listy do Gospodarza. Mokronosy, 2 lutego”, Gospodarz 9 II 1882: 3; „Rozmaitości”, Gospodarz 8 VI 1882: 3-4; „Sprawozdania z zebrań rolniczych”, Gospodarz 5 VII 1883: 3-4; „Listy do Gospodarza”, Gospodarz 27 IX 1883: 5; „Sprawozdanie z zebrań”, Gospodarz 3 I 1884: 3-4; „Listy do Gospodarza”, Gospodarz 6 III 1884: 3; „Listy do Gospodarza”, Gospodarz 14 V 1887: 4; „Listy do Gospodarza”, Gospodarz 1 IX 1888: 3; „Listy do Gospodarza”, Gospodarz 26 I 1889: 3; „Walne zebranie Kółek rolniczych”, Gospodarz 2 XI 1889: 2-3.

142 O planie umieszczenia tego swoistego informatora ruchu towarzystw rolniczych zawiadomiła redakcja w: „Od Redakcyi”, Gospodarz 25 II 1875: 4 - „Ponieważ w przyszłości mamy zamiar urządzić Kalendarz zebrań Towarzystw rolniczych w Gospodarzu, przeto wzywamy wszystkie Towarzystwa 
Toruński „Przyjaciel” w rocznikach 1875-1881 sporadycznie zamieszczał artykuły dotyczące organizacji rolniczych ${ }^{143}$. W rocznikach $1882-1890$ pisma zamieszczano najczęściej relacje dotyczące działalności następujących towarzystw rolniczych Prus Zachodnich: Towarzystwa Rolniczego w Wąbrzeźnie ${ }^{144}$, Kółka Rolniczego w Barłożnie ${ }^{145}$, Towarzystwa Rolniczego w Chełmży ${ }^{146}$, Towarzystwa Rolniczego w Kowalewie ${ }^{147}$ i Towarzystwa Rolniczego w Czersku ${ }^{148}$.

Podsumowując wspomniany materiał, należy stwierdzić, że tematykę dotyczącą działalności organizacji rolniczych polskich na rzecz rolnictwa zamieszczały na swoich łamach szerzej następujące pisma: „Nadwiślanin”, „Przyjaciel Ludu”, „Gazeta Toruńska” oraz, co zrozumiałe, pisma specjalistyczne: „Piast”, „Rolnik”, „Gospodarz”. Z pism politycznych najczęściej tematykę dotyczącą organizacji rolniczych zamieszczała „Gazeta Toruńska”, najmniej natomiast „Pielgrzym” i „Przyjaciel”. „Gazeta Toruńska" zajmowała się tematyką organizacji rolniczych najszerzej, przedstawiając swoje stanowisko wobec problemów tych organizacji. Pisma specjalistyczne - „Piast”,

i Kółka rolnicze, żeby nam raczyły nadsyłać jak najwcześniej ile możności z miesiąca na miesiąc swoje ogłoszenia o mających się odbyć zebraniach [...]”. Ogłoszenia dotyczące dat zebrań organizacji rolniczych w rubryce pt. Kalendarzyk zebrań zostały zamieszczone m.in. w następujących numerach pisma: Gospodarz 4 III 1875: 4; Gospodarz 11 III 1875: 4; Gospodarz 25 III 1875: 4; Gospodarz 1 IV 1875: 4; Gospodarz 8 VII 1875: 4; Gospodarz 23 IX 1875: 4; Gospodarz 4 XI 1875: 4; Gospodarz 6 I 1881: 4; Gospodarz 20 I 1881: 4; Gospodarz 10 II 1881: 4; Gospodarz 31 III 1881: 4; Gospodarz 11 VIII 1881: 4; Gospodarz 25 VIII 1881: 4; Gospodarz 15 IX 1881: 4; Gospodarz 29 IX 1881: 4; Gospodarz 27 X 1881: 4; Gospodarz 17 XI 1881: 4; Gospodarz 9 II 1882: 4; Gospodarz 9 III 1882: 4; Gospodarz 20 IV 1882: 4; Gospodarz 8 VI 1882: 4; Gospodarz 27 VII 1882: 6; Gospodarz 31 VIII 1882: 4; Gospodarz 5 X 1882: 4; Gospodarz 16 XI 1882: 4; Gospodarz 11 I 1883: 4; Gospodarz 1 II 1883: 4; Gospodarz 29 III 1883: 4, Gospodarz 26 IV 1883: 4; Gospodarz 31 V 1883: 4; Gospodarz 5 VII 1883: 4; Gospodarz 26 VII 1883: 4; Gospodarz 30 VIII 1883: 4; Gospodarz 4 X 1883: 4; Gospodarz 1 XI 1883: 4; Gospodarz 22 XI 1883: 8, Gospodarz 27 XII 1883: 4; Gospodarz 3 I 1884: 4; Gospodarz 31 I 1884: 4; Gospodarz 13 III 1884: 4; Gospodarz 27 III 1884: 4; Gospodarz 17 IV 1884: 4; Gospodarz 29 V 1884: 4; Gospodarz 12 VI 1884: 4; Gospodarz 26 VI 1884: 4. Od rocznika 1887 „Gospodarza” informacje o zebraniach towarzystw rolniczych były podawane także w ramkach lub artykułach znajdujących się przeważnie na stronie 1 lub 4 pisma, np.: Gospodarz 25 VI 1887: 4; Gospodarz 2 VII 1887: 4; Gospodarz 29 X 1887: 4. Rubryka pt. Kalendarzyk zebrań znalazła się w tym roczniku pisma tylko dwa razy: „Kalendarzyk zebrań”, Gospodarz 9 IV 1887: 4; „Kalendarzyk zebrań”, Gospodarz 3 XII 1887: 3; „Walne zebranie”, Gospodarz 20 X 1888: 1; „Walne zebranie”, Gospodarz 27 X 1888: 1; „Walne zebranie”, Gospodarz 12 I 1889: 4; „Walne zebranie prezesów i delegatów Kółek rolniczych”, Gospodarz 2 III 1889: 1; „Zebranie rolnicze w Chełmży”, Gospodarz 18 V 1889: 4; Gospodarz 1 VI 1889: 1 (artykuł bez tytułu); „Walne Zebranie”, Gospodarz 17 VIII 1889: 1; „Walne Zebranie”, Gospodarz 7 IX 1889: 1; „Walne zebranie”, Gospodarz 28 IX 1889: 1; „Walne zebranie”, Gospodarz 5 X 1889: 1; „Walne zebranie”, Gospodarz 12 X 1889: 1.

143 Np. „Odezwa”, Przyjaciel 14 VI 1877: 4 - odezwa dotyczy Kółka Rolniczego w Kowalewie; Przyjaciel 4 X 1877: 4 - ogłoszenie w ramce dotyczące Towarzystwa Rolniczego w Chełmży.

${ }_{144}$ Przyjaciel 1 VI 1882: 2 (artykuł bez tytułu).

145 „Kółko rolnicze w Barłożnie”, Przyjaciel 3 IV 1884: 2.

146 Np. Przyjaciel 2 XII 1886: 4 - ogłoszenie o zebraniu 5 XII 1886.

147 Przyjaciel 15 XI 1888: 4 - ogłoszenie o zebraniu 18 XI 1888.

148 „Towarzystwo rolnicze w Czersku”, Przyjaciel 23 X 1890: 1. 
„Rolnik” oraz „Gospodarz” - wspomnianej tematyce poświęciły, jeśli chodzi o proporcjonalną zawartość, drugie miejsce - po tematyce dotyczącej szeroko rozumianego poradnictwa gospodarczego.

\title{
Karol Staniszewski
}

\section{The Activities of Polish Farming Organizations in West Prussia between 1850 and 1890 in Support of Development of Polish Agriculture as Seen in the Pomeranian Polish-language Press}

\begin{abstract}
Summary
This article deal with the activities of Polish farming organizations in West Prussia between 1850 and 1890 in support of the development of agriculture. As opposed to writing on the subject up to now, this article approaches the issue in its entirety. The author considers the activities of Polish farming organizations in the context of competitive struggles with the German community in economic areas. The important aspects of this article include those relating to the "struggle" over Polish ownership in agriculture, but also the matter of the so-called praca u podstaw (work at the grass-roots). This subject was seen by the contemporary Polish press as a panacea that would make it possible to maintain Polish ownership at a time of increasing competition from Germans. The research material used in the article consists of Polish journals published in the years 1850 to 1890 in West Prussia, including "Gazeta Toruńska", "Gospodarz", "Nadwiślanin", "Piast", "Pielgrzym", "Przyjaciel”, "Przyjaciel Ludu”, and "Rolnik”.
\end{abstract}

